\title{
Teachers as Learners: Self-Regulated Learning Strategies During Covid-19 Pandemic in Indonesia
}

\author{
Adelina Mulyani Go ${ }^{1 *}$ Dody Kurniawan ${ }^{2}$
}

\author{
${ }^{1}$ Independent Researcher, Bekasi 17116, Indonesia \\ ${ }^{2}$ Independent Researcher, Tangerang 15811, Indonesia \\ *Corresponding author. Email: adelina.mulyani.go@gmail.com
}

\begin{abstract}
The year 2020 has somehow reformed many things in our life, especially in the education sector. As the pandemic occurred, the way of teaching and learning was transformed into the online world. Through all the changes happening during the pandemic, teachers need to adapt and learn new ways or skills to be able to cope and continue the teaching and learning process. This study seeks to understand the use of self-regulated learning strategies by teachers as learners in equipping themselves to teach during the pandemic. Four inservice secondary school teachers, who have experience in teaching both face-to-face and also online classes, were interviewed to get their stories by using open-ended questions regarding their learning journey to adapt to the new changes caused by the pandemic. The data is analyzed based on the adaptation of the SelfRegulated Learning strategies instrument developed by Zimmerman and Pons (1986, 1988, and 1990) and that yielded five themes. The results show that the characteristic of self-regulated learning strategies appeared in the teachers' stories, which include the Forethought Phase, the Performance Phase, and the Self-Reflection Phase. It is recommendable that teachers should be aware of their perceptions and colleagues for these two are building blocks that support them to learn new things, especially in the midst of challenges.
\end{abstract}

Keywords: Self-regulation learning, self-regulated learning strategies, teacher as learner, distance learning, online teaching, covid-19, Indonesia, pandemic

\section{INTRODUCTION}

Rapid changes keep on happening in the world especially due to the Covid-19 pandemic, where we are faced with various challenges [1]. Since the announcement of the movement restriction order in Indonesia at the beginning of 2020, learning activities have switched from face-toface to distance learning [2]. The distance learning gradually switched to hybrid learning in some schools to cater students' circumstances. At the end of 2020, it was announced that face-to-face learning could be implemented again in school with strict health protocols. However, the regulations regarding schooling constantly change from time-to-time with short notice [3], [4]. Therefore, the demand for mastering self-regulation learning skills has increased even more, not just for students but also for teachers as learners to adapt to these new circumstances.

For the past 20 years, there have been numerous research on self-regulation learning focusing on students' learning [5]-[9] and how teachers are contributing as agents to reinforce self-regulation learning [10]. However, there is still very little research on how teachers as learners implement self-regulation learning in developing themselves. To be an agent who acts to introduce and reinforce students' SRL experience [11], teachers need to learn to become more proactive self-regulated learners themselves [12]-[15]. This study is developed to fill in that gap and to understand the use of self-regulated learning strategies by teachers as learners in equipping themselves to teach in new approaches during the pandemic. Hence, the research question of this study is: In the light of Self-Regulated Learning strategies, how do teachers develop Self-Regulated Learning skills during the Covid-19 pandemic?

\subsection{Self-Regulated Learning}

Self-regulated learning is a full-engagement activity including multiple parts of the brain, which requires full attention and concentration, self-awareness and reflection, honest self-assessment, openness to improvement, authentic self-discipline, and acceptance of responsibility for one's learning [7], [16]. Based on the various research, it is evident that implementation of self-regulated learning (SRL) in school settings upturns the success in problemsolving, academic achievement, intrinsic motivation and task interest [5], [7], [17], [18]. Furthermore, selfregulatory skills equip students to manage their social behaviour by being able to have more positive views towards their future, which support the development of 
lifelong learning skills, and such skills related to human agency are essential to cope with the challenges of contemporary society [19]. Especially with what has been happening where schooling has been transformed by the pandemic, the importance of self-regulation learning skills have been more visible.

\subsubsection{Teachers'self-regulation as learners}

In this study, we are focusing on the teachers' ability to implement their self-regulated learning known as the learners' role [11], [15], based on the usage of selfregulated learning strategies while they are learning new ways of distance teaching to equip themselves to teach online during the pandemic. Teachers' self-regulation as a learner is a constructive and proactive process where the teachers set goals and attempt to monitor and evaluate their cognition, motivation, and behaviour towards the learning process, while directed by contextual features in the environment [20]. The self-regulated learning is following the cynical process that includes three phases; (1) Forethought Phase, which revolves around goal setting of specific activities, resources, and time allocation; (2) Performance Phase, where teachers use their goals to monitor the process and move it along; (3) Evaluation Phase, when teachers use information gained from the completed task to improve the next task's performance [21]

Table 1 Phases of the teacher as a learner as reflected in their actions and consideration (what/how/why/ and by whom) - [11]

\begin{tabular}{cl}
$\begin{array}{c}\text { Self-regulatory } \\
\text { Phase }\end{array}$ & \multicolumn{1}{c}{ Teachers' self-regulation as a learner } \\
\hline $\begin{array}{c}\text { Forethought } \\
\text { Phase }\end{array}$ & $\begin{array}{l}\text { Teacher actions and consideration are directed } \\
\text { to his/her SRL }\end{array}$ \\
& $\begin{array}{l}\text { Sets goals, plans specific activities, resources, } \\
\text { and time allocation by taking control over the } \\
\text { topic (What \& When) }\end{array}$ \\
& $\begin{array}{l}\text { Draws from prior experiences to inform } \\
\text { planning (When \& How) }\end{array}$ \\
& $\begin{array}{l}\text { Selects strategies that best fit the lesson topic } \\
\text { (When \& How) }\end{array}$ \\
Pays attention to increasing sustain motivation \\
(Why)
\end{tabular}
$\begin{array}{ll}\begin{array}{l}\text { Self-reflection } \\ \text { (Evaluation) }\end{array} & \begin{array}{l}\text { Attributes successes and failures to the choice } \\ \text { made (Why) }\end{array}\end{array}$

Pays attention to use information gained from the completed task to improve performance on the next task (why)

This role is taken as the focus of this study because as an agent who acts to introduce and reinforce students' SRL experience, teachers need to learn to become more proactive self-regulated learners themselves [12]-[15]. When teachers are able to be proactive self-regulated learners, they will be able to implement 'self-regulation as teachers' (SRT), which is known as teachers' dual selfregulation process. Teachers' SRT is shaped by their own self-regulation learning experiences and by feedback gathered through the teaching experiences where students actively construct their personal self-regulation learning [11].

\subsubsection{Self-regulated Learning strategies}

Self-regulation theory focuses attention on why and how learners initiate and control their learning [22]. To be able to view how teachers (the learners in this context) apply self-regulated learning, specific learning strategies are evaluated as they engage in a learning task or process. Self-regulated learning strategies means by action detected at gathering information or skills that involve agency, goals, and instrumentality self-perception by a learner [23].

This instrument that was developed by Zimmerman \& Pons $(1986,1988,1990)$ which was used to assess SRL as a metacognitive, motivational, and behavioral construct is known as the Self-Regulated Learning Interview Scale (SRLIS). During this structured interview, students were asked to respond according to six learning contexts: in (1) classroom situation, (2) at home, (3) when completing writing assignments outside of class, (4) when completing math assignment outside class, (5) when preparing for and taking a test, and (6) when being poorly motivated. The answers to these open-ended questions are transcribed and coded into 14 self-regulatory categories that focus on motivation, metacognition, or behavior. Self-evaluation reactions and self-consequences are included among the motivation categories. Goal setting and planning, organizing and transforming, seeking information, and rehearsing and memorizing are included among the metacognitive categories. Environmental structuring; keeping records and monitoring; reviewing texts, notes, and tests; and seeking assistance are included among the behavioral categories. The frequency of the strategies used was recorded according to each learning context. Students were also asked to rate their consistency in using a particular strategy using a 4-point scale that ranges from seldom to most of the time. Research by Zimmerman and Pons (1986) shows a substantial correlation between students' self-reported strategies use and their academic 
achievement. A further study was done by the same researchers that confirmed this relationship between the strategies used and academic achievement and also demonstrated the link between students' perception of both verbal and mathematical efficacy and the use of selfregulated strategies (Zimmerman \& Pons, 1988, 1990).

\section{METHODS}

\subsection{Participants}

Four in-service teachers participated in this study. They are teaching in a secondary school located in Bekasi, Indonesia. The teachers have been teaching in the school before the pandemic occurred. They have experience in face-to-face teaching, distance learning, and also hybrid teaching and learning. The participants consist of three male and one female teacher. The teachers' teaching experience range from 3 to more than 9 years of teaching.

Table 2 Participant's profile in this study

\begin{tabular}{cccc}
\hline Pseudonym & Gender & Grade Level & $\begin{array}{c}\text { Years of } \\
\text { Teaching }\end{array}$ \\
\hline Teacher A & Male & 11 and 12 & $>9$ Years \\
Teacher B & Male & 10,11 and 12 & $>9$ Years \\
Teacher C & Male & $8,9,10$, and 11 & $3-6$ Years \\
Teacher D & Female & 9,11 and 12 & $>9$ Years \\
\hline
\end{tabular}

\subsection{Methodology}

This research utilised narrative inquiry to understand the teachers' lived experiences [26, p. 21], [27]. The researchers delved into teachers' lived experiences through various forms of narrative materials such as their stories and personal learning notes, to generate meaning, insights, and understanding [28]. Since the stories that the teachers narrated were always situated in a particular time, space, and social relations within a specific context [29], the researchers might be able to extract insights and principles from the actions that the teachers took both as a person or a group of people in a community to adapt to the full online teaching. In line with Atkinson's (2007) view, the teachers will tell what is meaningful, important, and significant for them. Hence, the stories would provide clues for the researcher to "gave voice" and revealed the process of how the teachers found meaning and importance of their experiences in adapting to the full online teaching.

\subsection{Instrument}

The interview questions are adapted from Zimmerman \& Pons' $(1988,1986,1990)$ interview which was used to assess SRL as a metacognitive, motivational, and behavioural construct which is the Self-Regulated Learning Interview Scale (SRLIS). The questions are divided into three main stages; (1) Recalling main events, (2) Storytelling about the Self-Regulated Learning strategies used and follow-up questions, (3) Closing statement or conclusion of the interview. In line with Goodley's (in [31]) view of that the narrative interview should be open-ended, so the prepared questions in this study were used as a guide only that the participants could specify elements that are important to them on their own accord. This view is supported by Atkinson (1998) who claims that an open-ended interview provides a space for the participants to tell their stories. Moreover, Firmin (2008) suggests that the interviewers should not superimpose their ideas on the participants. The interview should be a moment where participants could articulate their ideas without external predetermined force, so-called the participant-led interview. Thus, this study employed open-ended interviews to ensure the teachers were given enough space in narrating their stories which include a moment of clarification and a freedom for not answering questions that they did not want to.

There were three steps of instrument validation to ensure its trustworthiness. First, the researchers scrutinized the questions in the light of academic literature, which pertain to Zimmerman \& Pons' $(1988,1986,1990)$ works. Second, the instrument was blind reviewed for feedback and revision. Last, it was also checked and approved by the participants prior to the interview to make sure the questions were understandable and relevant in their context.

\subsection{Procedure}

Participants were approached through email and then filling an online consent form. Participants were briefed through an online briefing prior to the interview to establish rapport, clarify things, and prepare them to be ready for the actual interview. After the participants understood the context of the interview, both the researchers and the participants met virtually at the agreed time. The meetings were recorded for the data analysis purpose per the participants' consent.

\subsection{Data Analysis}

For the purpose of this study, the participants' stories were transcribed into written text for analysis [34, p. 13]. The researchers then colour coded the text and organized the information from the stories according to the categories based on an instrument developed by Zimmerman \& Pons $(1986,1988,1990)$ and phases of the teachers as learners as reflected in their actions and consideration (what/how/why/ and by whom) [11]. Based on the organized data, the findings of this study are organized in themes that show the participants' process of formulation 
of self-regulated learning strategies as they carried out their duty as teachers in full online teaching setting. Afterward, the themes were discussed in the views of SelfRegulated Learning theories.

\section{FINDINGS}

The teachers' stories show there are five themes of the strategies that lead the teachers to develop the SelfRegulated learning skills during the Covid-19 pandemic.

\section{It began with "the great chaos"}

It began with "the great chaos" that was signified by two characteristics, one, no time for preparation, and two, panic attack. The story from teacher $\mathrm{E}$ depicted the situation where she, who is a mathematics teacher, really had no idea how the online platform could even work. She had no experience in utilizing any online platforms for teaching purposes (i.e. virtual whiteboard) at all before the period of online teaching. Also, the unimagined ideal form of online teaching mechanism was one reason that led her to the panic attack in the first two weeks of full online teaching.

"I got panicked and did not know what to do. How could I write equations on online platforms as I did on the whiteboard? I did not know! I never used any online platforms before! I did not know how online teaching in Mathematics would look like if I had to do it by myself"

(Teacher E)

Likewise, teacher A described the period of "the great chaos" as when one goes into a jungle without any preparation. This situation had also led him to a moment of panic for he was uncertain of what was best to be done.

"I will say that the experience to teach fully online without preparation is like I went into the jungle"

(Teacher A)

Although the teachers were struggling at the beginning of the full online teaching, it is obvious that it happened due to due to the issue of novelty, that the teachers had never done it before. This is in line with what Teacher D said, "I never used any online platforms before!".

\section{A perception of a universal common challenge}

After going through several weeks of the full online teaching, the teachers started to perceive the online teaching as a universal common challenge. They perceived it as an unavoidable constraint that impacted teachers universally.

"I am still on a group of teachers from my previous work. They are also struggling. They don't know what to do either." (Teacher A)

The teachers' involvement in various communities strengthened this perception which gave them a confirmation that everybody was struggling. This perception had engendered hope and courage for the teachers to embrace the fact that they must teach online and that they needed to acquire new knowledge of online teaching.

"I am still on a group of teachers from my previous work. They are also struggling. They don't know what to do either." (Teacher A)

The perception of the universal common challenge also had engendered a sense of solidarity among the teachers to support one another which never happens before. There existed a generic support system that allows the teacher to share knowledge and learn one from another.

"before the pandemic, everybody has an issue, but nobody really cares. But during the pandemic, it is 'our' common issue, so we must support each other. (Teachers B)

Moreover, their perception also engendered selfdetermination and self-initiative to learn from others independently. The teachers' stories revealed that they attended various virtual training sessions to better equip themselves in online teaching. The teacher $\mathrm{D}$ even mentioned that she was surprised by the number of ecertificates that she got in this period of online teaching.

\section{The source of motivation and support system}

The teachers' stories also suggest the presence of people around that motivated the teachers to keep on findings better ways of teaching online. As for teacher $\mathrm{A}$, it is obvious that his daughter had inspired him to keep on seeking new ways of teaching. He was sincerely certain that he should be someone whom he would expect from her daughter's future teacher would be. For this reason, he should not give in to the situation.

"I want to be a teacher that I image my daughter will have in the future" (Teacher A)

Teacher E too, described her students as the agents that empowered her to keep on learning and trying something new, as she realized online learning would be challenging for the students as well. Although she did not have prior knowledge on how to teach Mathematics online, she determined that the students' right to learn must not be hindered because of online learning.

"I have to prepare my lesson well. I am the teacher for the students, and it is my responsibility to give my best. I must not give in to the situation. I have to ensure that the students go on learning despite the limited situation due to pandemic" (Teacher D)

The emergence of a collegial support system is something in common that is found in all teachers' stories. The teachers described this support system as a community of learners who shared their best practices of online teaching that they learned through trial and error. They had a database that portrayed a list of apps that were used by teachers with notes on their effectiveness and/or limitations. They also had a regular meeting where teachers with new knowledge would come and share with 
others his/her best practices. According to the teachers' stories, they found this meeting to be very helpful to provide them references of what to do in their lesson.

"We do have a weekly meeting where the teachers will meet up to share what they did in their class" (Teacher A)

"Every week, we have a sharing session where each teacher will share what apps that they used in their class"

(Teacher B)

Moreover, within the school system, the teachers' stories also specifically highlight the presence of a coordinator who was in charge of the development and integration of technology into teaching-learning practices. The very agent was described as someone available to give and/or seek an answer to any technical questions that were faced by the teachers.

"I am so thankful for we have Mr. A. He is always available to answer my questions" (Teacher D)

"Mr.A is our coordinator who shares us strategies that we can do in our virtual classroom. Recently, we just learn how to create breakout rooms virtually" (Teacher C)

\section{Teacher strategies in learning}

Despite the fact that the teachers had a community of learners where they could learn one form another, the teachers also mention their strategies in learning new ways of teaching. Teacher $\mathrm{A}$ and $\mathrm{C}$ described their learning as a spontaneous process without any specific plans or objectives. They learned mostly from free online resources and attending online seminars that had led them to enjoy the new routine that they had. After doing independent learning for about three months, Teacher A said that he was somewhat addicted to the learning process, and teacher $\mathrm{C}$ described his independent learning process as something fun that he had learned during this time.

"it seems that I am addicted (to learning) because of this process" (Teacher A).

"As for me, it is quite fun though. It (the online teaching) forces me to learn many new things (Teacher C)"

Teacher B too highlighted the importance of having enough time for himself to try a technique or method of teaching before implementation. During the trial period, he would predict any possible errors that might occur in a real teaching setting. For teacher B, he needs to have enough self-confidence before implementing any particular methods.

"It took a lot of time. If (I am) not sure, I will not implement it in my class. I don't want to waste my (faceto-face) teaching duration (because of technical issue)"

(Teacher B)

For teacher D, she described her learning process as a comparative-based process. She realized that she was not someone who was into technology, and hence, she needed someone to teach her how to function the online platforms that were used. From teacher D's stories, there are two characteristics of her learning strategy. Firstly, she would clearly define what she needed to conduct her online teaching. For her, it is essential to know what she needed so that she could prioritize what to learn in the very limited amount of time that was available. She got references for what she needed through observation of what others did when she attended various online seminars. She describes her curiosity as self-comparison and imitation. She was certain that she could also do what others did.

"I think I learn through comparison. I am always curious how they did that (changing backgrounds). I always want to do it in my class. However, I will pick and choose things that are essentials for me. I can't learn everything for I know I am slow in technology. I prioritize what I need to learn" (Teacher E)

After defining what she needed and realizing her limitations in learning new technology, she would ask help from the right people who she described as someone with a passion for learning, that is, someone who might not be an expert, but he/she was into learning. The very person was the coordinator in technology whom teacher D referred to as someone she bothered many times.

"I am so grateful to have Mr.A in our school. He might not be the expert, but he is always available whenever I need help and willing to seek an answer to my question. I am the one who asks him (Mr.A) question the most. (Teacher

\section{New Insights: The strengths of the online teaching}

When the teachers told about their experiences with full online teaching, they also mentioned its benefits. There are three benefits of online teaching that are suggested from the findings. One, online teaching enables the students to make sure each student is having the same materials (Teacher C), two, teachers could make sure that each student will have their learning notes from each learning session (Teacher B), and three, the teacher could ensure all students get learning instructions (Teacher D). These benefits were from the online platforms that were used by the teachers that allowed them to record lessons and collect students' work virtually immediately.

"Through an online platform, I could make sure that each student has his/her learning notes" (Teacher B)

"I would send my teaching note to the students right away by the end of each session. In this way, all students have the same materials as I do" (Teacher C)

"I always record my teaching and learning instructions that can be reviewed by the students. So, the students will find no excuse for not knowing the instruction" (Teacher D)

Indeed, the unexpected full online teaching has posed challenges to the teachers and also led them to learn many new things. For these teachers, instead of giving in to the situations, they seek opportunities to overcome them.

\section{DISCUSSION}

The findings of this study confirm the elements of selfregulated learning by Kramarski (2018). The first theme 
signifies the teachers' period of self-evaluation which is in line with the Forethought Phase when the teachers drew from their past experiences, so-called face-to-face teaching practices, which were no longer relevant in full online teaching settings. For this reason, the 'panic attack' that was experienced by the teachers can be understood as a product of their self-evaluation in the form of the teachers' natural response toward their 'present' situation. It is evident that through this phase, the teachers were urged to formulate online teaching strategies immediately. Interestingly, the second theme about their perception of common challenge highlights that is little known about the role of one's perception of a globalised phenomenon with the development of his/her self-regulated learning skills. This finding is consistent with Olafson \& Shraw, (2010) who suggested the role of teachers' personal beliefs in formulating their instructional pedagogy. Hence, it is interesting to note that involvement with a different group of people virtually who get impacted by the very same phenomenon, could be a stepping stone for one to rationalize one's present situation. However, a further study of it should be done to understand more what sort of the characteristics, interactions, and relationships that the virtual group has.

As for the third theme, it is in line with the Performance Phase [11], [36], where the teachers could get feedback, information, and knowledge to think of adjustments for their practices. It is notable that the presence of an agent who is designated to assist the teachers with technicalities in online teaching. Availability and willingness to keep searching for an answer to the teachers' question are considered more important than his/her expertise. Hence, further research on the emergence of a new role of this sort should be done.

The findings of teachers' strategies in learning during the full online teaching period align well with the very definition of self-regulated learning by various researchers [11], [15], as well as confirm both the Performance Phase and the Self-Evaluation phase [5]-[7], [11]. Having a routine for independent learning, time for rehearsing, as well as learning through imitations are identified as key characteristics of the teachers' attempt to adapt to the full online teaching. One concern about the findings of teachers' strategies was that no generalisation could be made. The findings show that each teacher demonstrated different learning strategies.

It is somewhat surprising that 'the great chaos' ended with 'new insights'. The findings confirm that the teachers paid attention to the new knowledge that they acquire from their learning process. The fact that they could point out the benefits of the full online teaching and know how to use it to improve their teaching practices are in line with the Evaluation Phase of self-regulated learning [11], [36].

\section{CONCLUSION}

Based on this narrative inquiry conducted, the results show that the characteristic of self-regulated learning strategies appeared in the teachers' stories, consisting of the
Forethought Phase, the Performance Phase, and the SelfReflection Phase. It is recommendable that teachers should be aware of their perceptions and colleagues for these two are building blocks that provide them with support system to learn new things, especially in the midst of challenges. However, a perspective on the matter is still one-sided from the teachers in a school with a qualitative approach which might not be able to generalize the larger sum of teachers' perspective. A longitudinal study which involved more teachers in a number of schools will provide a better understanding regarding this issue. It is also beneficial if another study is carried out to include students' perspective as additional factor to draw deeper understanding toward the self-regulation learning both from teachers and students.

\section{REFERENCES}

[1] J. Kim, "Learning and Teaching Online During Covid-19: Experiences of Student Teachers in an Early Childhood Education Practicum," Int. J. Early Child., vol. 52, no. 2, pp. 145-158, 2020, doi: 10.1007/s13158020-00272-6.

[2] MENDIKBUD RI, "Pembelajaran secara Daring dan Bekerja dari Rumah dalam Rangka Pencegahan Penyebaran Corona Virus Disease (COVID- 19)," in Mendikbud RI, 2020, pp. 1-2, [Online]. Available: https://www.kemdikbud.go.id.

[3] Kemdikbud RI, "Penyelenggaraan Pembelajaran Pada Semester Genap Tahun Akademic 2020/2021," Http://Kemdikbud.Go.Id/, 2020, [Online]. Available: http://kemdikbud.go.id/main/?lang=id.

[4] R. Efendi, "Penyelengaraan Pembelajaran Semester Genap Tahun Ajaran 2020/2021 di Kota Bekasi." Bekasi, 2021.

[5] B. J. Zimmerman, Motivational Sources and Outcomes of Self-Regulated Learning and

Performance. Routledge, 2011.

[6] E. Panadero, "A review of self-regulated learning: Six models and four directions for research," Front. Psychol., vol. 8, no. APR, pp. 1-28, 2017, doi: 10.3389/fpsyg.2017.00422.

[7] L. B. Nilson and B. J. Zimmerman, Creating SelfRegulated Learners, First Edit. Virginia: Stylus Publishing, 2013.

[8] A. M. Go, "Student's Motivational Goal Orientation in Facing National Exam in Indonesia," University of Oulu, 2018. 
[9] P. R. Pintrich, "The Role of Goal Orientation in Self-Refulated Learning," in Handbook of SelfRegulated Learning, M. Boekaerts, M. Zeidner, and P. R. Pintrich, Eds. 2000.

[10] B. Kramarski and T. Revach, "The challenge of self-regulated learning in mathematics teachers' professional training," Educ. Stud. Math., vol. 72, no. 3, pp. 379-399, 2009, doi: 10.1007/s10649-009-9204-2.

[11] B. Kramarski, "Teachers as agents in promoting students' SRL and performance: Applications for teachers' dual-role training program," in Handbook of self-regulation of learning and performance (p. 223, Routledge/Taylor \& Francis Group, 2018, pp. 23-239.

[12] H. Bembenutty, "The triumph of homework completion through a learning academy of selfregulation," in Applications of self-regulated learning across diverse disciplines: A tribute to Barry J. Zimmerman, H. Bembenutty, T. . Cleary, and A. Kitsantas, Eds. IAP Information Age, 2013, p. 1530196.

[13] C. D. Ewijk and G. Büttner, "Assessing How Teachers Enhance Self-Regulated Learning: A Multiperspective Approach," J. Cogn. Educ. Psychol., vol. 12, no. 3, pp. 338-359, 2013.

[14] B. Kramarski and T. Michalsky, "Investigating Preservice Teachers' Professional Growth in SelfRegulated Learning Environments," J. Educ. Psychol., vol. 101, no. 1, pp. 161-175, 2009, doi:

$10.1037 / \mathrm{a} 0013101$.

[15] J. Peeters, F. De Backer, V. R. Reina, A. Kindekens, T. Buffel, and K. Lombaerts, "The Role of Teachers' Self-regulatory Capacities in the Implementation of Self-regulated Learning Practices,' Procedia - Soc. Behav. Sci., vol. 116, pp. 1963-1970, 2014, doi: 10.1016/j.sbspro.2014.01.504.

[16] D. . Schunk and J. A. Greene, Handbook of SelfRegulation of Learning and Performance, Second. New York and London: Routledge, 2017.

[17] B. J. Zimmerman, a. Bandura, and M. MartinezPons, "Self-Motivation for Academic Attainment: The Role of Self-Efficacy Beliefs and Personal Goal Setting," Am. Educ. Res. J., vol. 29, no. 3, pp. 663-676, 1992, doi: 10.3102/00028312029003663.

[18] C. Mega, L. Ronconi, and R. De Beni, "What makes a good student? How emotions, self-regulated learning, and motivation contribute to academic Achievement," J. Educ. Psychol., vol. 106, no. 1, pp.
121-131, 2014, doi: 10.1037/a0033546.

[19] A. Bandura, "Toward a Psychology of Human Agency," Perspect. Psychol. Sci., vol. 1, no. 2, pp. 164180, 2006, doi: 10.1111/j.1745-6916.2006.00011.x.

[20] B. J. Zimmerman, "Investigating self-regulation and motivation: Historical background, methodological developments, and future prospects," Am. Educ. Res. J., vol. 45, no. 1, pp. 166-183, 2008, doi: $10.3102 / 0002831207312909$.

[21] E. . Usher and D. . Schunk, "Social cognitive theoretical perspective of self-regulation," in Handbook of self-regulation of learning and performance, Routledge/Taylor \& Francis Group., 2018, pp. 19-35.

[22] N. Purdie, J. Hattie, and G. Douglas, "Student Conceptions of Learning and Their Use of SelfRegulated Learning Strategies: A Cross-Cultural Comparison," J. Educ. Psychol., vol. 88, no. 1, pp. 87100, 1996, doi: 10.1037/0022-0663.88.1.87.

[23] B. J. Zimmerman and M. M. Pons, "Development of a Structured Interview for Assessing Student Use of Self-Regulated Learning Strategies," Am. Educ. Res. J., vol. 23 , no. 4 , pp. 614-628, 1986, doi: $10.3102 / 00028312023004614$.

[24] B. J. Zimmerman and M. Martinez-Pons, "Construct validation of a strategy model of student self-regulated learning.," J. Educ. Psychol., vol. 80, no. 3, pp. 284-290, 1988, doi: 10.1037//00220663.80.3.284.

[25] B. J. Zimmerman and M. M. Pons, "Student Differences in Self-Regulated Learning: Relating Grade, Sex, and Giftedness to Self-Efficacy and Strategy Use," J. Educ. Psychol., vol. 82, no. 1, pp. 5159, 1990, [Online]. Available:

http://www.tandfonline.com/doi/abs/10.1080/00461520 701263426\%0Ahttp://doi.wiley.com/10.1111/j.14679647.2011.00772.x.

[26] D. J. Clandinin and F. M. Connelly, Narrative inquiry: Experience and story in qualitative research. San Fransisco: Jossey-Bass Publishers., 2000.

[27] R. Josselson, "The present of the past: Dialogues with memory over time," J. Pers., pp. 647-668, 2009.

[28] J.-H. Kim, Understanding narrative inquiry: The crafting and analysis of stories as research. California: Sage, 2016. 
[29] K. Pyhältö, J. Pietarinen, and K. \& Salmela-Aro, "Teacher-working-environment fit as a framework for burnout experienced by Finnish teachers," Teach.

Teach. Educ., vol. 27, no. 7, pp. 1101-1110, 2011.

[30] R. Atkinson, "The Life Story Interview as a Bridge in Narrative Inquiry," in Handbook of narrative inquiry: Mapping a methodology, D. J. Clandinin, Ed. California: Sage Publications, 2007, pp. 224-245.

[31] P. Banister, Qualitative methods in psychology: A research guide, 2nd ed., vol. 2. New York: Open University Press, 2011.

[32] R. Atkinson, The life story interview. California: Sage Publications, 1998.

[33] M. Firmin, "Unstructured interview," in The SAGE encyclopedia of qualitative research methods, L. M. Given, Ed. California: Sage Publications, 2008, pp. 906-908.

[34] D. E. Polkinghorne, "Narrative configuration in qualitative analysis. In:," in Life history and narrative, J. Hatch and R. Wisniewsky, Eds. London: Falmer Press, 1995, pp. 5-23.

[35] L. Olafson and G. Shraw, "Beyond epistemology: assessing teachers' epistomolohical and ontological worldviews," in Personal Epistemology in the Classroom: Theory, Research, and Implications for Practice, L. D. Bendixen, Feucht, and F. C, Eds, New York, 2010, pp. 516-551.

[36] M. C. White and H. Bembenutty, "Teachers as Culturally Proactive Agents through Cycles of Self Regulation," Pap. Present. Queens Coll. Dep. Second. Educ. Youth Serv. Res. Sym-posium., no. October 2014, pp. 1-15, 2014, [Online]. Available: www.researchgate.net/publication/278036393. 